\title{
ウレテロマットを使用した硬性尿管鏡操作の臨床成績
}

\begin{tabular}{|c|c|c|c|c|c|}
\hline & 慶爪 & 塾大空 & 院 & 学教室 & \\
\hline 場 志良 & 増田 & 毅 & 朝倉 & 博孝 & 橘 \\
\hline 修宏 & 実川 & 正道 & 畠 & 亮 & 田崎 \\
\hline
\end{tabular}

\section{CLINICAL EXPERIENCE WITH URETEROMAT IN TRANSURETHRAL URETERORENOSCOPY}

\author{
Shiro Baba, Takeshi Masuda, Hirotaka Asakura, Masaaki Tachibana, Nobuhiro Deguchi, \\ Seido Jitsukawa, Makoto Hata and Hiroshi Tazaki \\ Department of Urology, Keio University, School of Medicine
}

By September 1988, we performed 58 ureterorenoscopies (52 for primary ureteral calculi, 3 for ureteral biopsy, 2 for ureteral stricute and 1 for ureteral foreign body) using a Ureteromat (Uromat Storz, West Germany). Continuous saline irrigation with the Ureteromat has obviated mechanical dilation of the ureteral orifice in $93.1 \%$ of the cases, which made this endoscopy as easy as the conventional cystourethroscopy. In 4 cases (6.9\%), however, balloon dilation of the ureteral orifice was necessary for the passage of a rigid ureterorenoscope.

Of 52 ureteral calculi, 37 were assigned for transurethral ureterolithotripsy (TUL), whereas transurethral ureterorenoscopy (TUURS) was indicated to flush the remaining 15 calculi up into renal pelvis for later extracorporeal shock wave lithotripsy. TUL was successful in $81.1 \%(30 / 37)$. The causes of failure were stone migration in 6 cases and ureteral avulsion by electrohydraulic lithotripsy necessitating open surgery in 1 case. The irrigation with the Ureteromat facilitated the manipulation of intraluminal ureteral lesions always under clear vision; by-passing the impacted stone with a guide wire and flushing-up of the calculi were successfully performed in $100 \%$, in spite of the co-existing edematous and inflammatory mucosal changes.

In 7 cases where ureteroscope could not be advanced well up to the lesion because of spasm in the iliac ureter, the irrigation pressure was transiently increased up to $200 \mathrm{mmHg}$ to allow safe and easy dislodgement of impacted calculi under fluoroscopic guidance. This procedure was also effective to introduced a ureteral stent over a guide wire in 2 cases of ureteral stricture, which could not be achieved by conventional cystoscopic procedure.

Immediate postoperative complications were fever in $8.6 \%$ and gross hematuria lasting for more than 4 days in $8.6 \%$. Intravenous urogram obtained in 50 patients after 3,6 and 12 months disclosed no remarkable adverse effects on the upper urinary collecting system, except for a mild hydroureter in one patient requiring no surgical intervention.

It is concluded that TUURS using a Ureteromat is a safer and more feasible method than any technique previously reported for the passage of a rigid ureterorenoscope.

要旨：経尿道的に硬性尿管鏡操作（TUURS）を行なった58例（尿管結石症例52例，上部尿路腫瘍 3 例, 尿管狭窄 2 例，尿管内異物 1 例）に尿管鏡潅流装置ウレテロマットを使用しその有用性について検討し た。 ウレテロマットによる高圧潅流により外尿道ロより膀腃内に硬性尿管鏡を直視下に誘導した。壁内 尿管粘膜の観察は容易で， 54 例 $(93.1 \%)$ に機械的尿管口㧪張法を使用せずに尿管鏡の插入に成功した。 のこりの 4 例には拡張用バルーンカテーテルを用いて插入に成功した。尿管鏡の上昇を阻止するような 尿管内腔異常所見が33例 $(63.5 \%)$ によれた。結石嵌部位での浮腫状粘膜変化がもっとも多く，つい で腸骨領域での尿管の痉挛的収縮が問題となった。ウレテロマットの潅流圧を一時的に上げても，これ らの内腔異常所見を改善することはできなかった。しかし加圧により内視鏡視野は著明に改善し，また 結石嵌頓部位をこえてガイドワイヤーを送り込む操作はきわめて容易となった。さらには ESWLのた 
めに嵌頓部位から結石を腎孟内に挙上することも100\%に可能であった。術前よりTULの適応となった 37 例の尿管結石症例での成功率は $81.1 \%$ あった. 術後 1 年間の経過を IVP で検討しえた 50 例のうち 1 例に壁内尿管の狭窄を疑わせる軽度の水尿管が認められたが，腎機能の悪化はみられていない，術後の 発熱もウレテロマットを使用しない諸家の報告と同等の頻度であった。

1980年に硬性尿管鏡が Perez-Castro と MartinezPineiro により報告 ${ }^{1)}$ れて以来, 泌尿器科医にとって 上部尿路に対する内視鏡操作はきわめて日常的なもの となった.とくに下部 $1 / 3$ 尿管結石には経尿道尿管鏡操 作（transurethral ureteroscopy：以下 TUURS）が有 効で，従来のレントゲン透視下のみでのバスケットカ テーテル操作はその尿管損傷の危険のゆえにほとんど 行なわれなくなった2).さらには体外衝撃波砕石術 （ESWL）の普及に伴い中部，上部 $1 / 3$ 尿管に嵌頓した 結石にも TUURSにより直視下に尿管内腔を観察し ながら結石を腎孟内に挙上することが安全に行なえる ようになった。しかし硬性尿管鏡の尿管内への插入は 術者の少なからざる経験が要求される。また尿管口や 壁内尿管の機械的拡張も重要で, Lyon ら ${ }^{3)}$ によれば $11.5 \mathrm{~F}$ の硬性尿管鏡を插入するために $16 \mathrm{~F}$ までのブ ジーによる拡張が必要とされている，最近の欧米での 報告では尿管口の機械的拡張法による硬性尿管鏡の插 入不能である確率は $7 \%$ 前後とされて打り4)5，さらに はこれらの尿管口拡張法は膀脱鏡を用いて行ならため 時間がかかりレントゲン透視下で行なわれるため壁内 尿管の損傷を抗こしやすい欠点がある6).

我々は最近 Perez-Castro ${ }^{71}$ により開発された尿管鏡 潅流装置ウレテロマット（Uromat: Storz，西独）を 使用し58例の TUURS 症例に直視下で尿管口ならび に壁内尿管を拡張する経験を得たので以下にその臨床 成績を報告する。

\section{対象および方法}

対象は昭和 62 年 1 月より昭和 63 年 9 月までに慶応義 塾大学病院泌尿器科で TUURSを施行した58例（男 36，女22）である。年齢は18歳から68歳までであった （平均 \pm S.D. ； $44.0 \pm 14.3$ ). 右尿管は19例, 左尿管は39 例であり, TUURS の適応となった疾患は尿管結石が もっとも多く52例で, 以下上部尿路腫瘍 3 例, 尿管狭 窄 2 例拉よび腎㙉内異物が 1 例であった，全例に尿路 感染症は認められなかった。 上部尿管結石 13 例のうち の10例 (77\%)，中部尿管20例のうちの 5 例（25\%）は ESWLを前提として入院したが結石の嵌頓していた 期間が 3 カ月以上で ESWLによる碎石が困難と予想 された症例である。いずれの症例でも嵌頓部位の尿管
粘膜が浮腫状変化のため尿管カテーテルのみでは結石 の腎盂内挙上が困難であり最終的に尿管鏡操作を必要 とした。これらの症例を除くと当初から経尿道的尿管 結石摘出術 (以下 TUL) の適応となった尿管結石症例 は37例であった，結石の長径は $9.0 \pm 3.3 \mathrm{~mm}$ ，短径は $6.2 \pm 1.9 \mathrm{~mm}$ (mean \pm S.D.) であった。 上部尿路腫瘍 の 3 例は粘膜病変の生検の目的で，また尿管狭窄の 2 例は尿管ステントカテーテルを膀胱鏡下で插入できず TUURSの適応となった。

麻酔は 2 例の腰椎麻酔を除き全例が全身麻酔で患者 体位を半載石位とした。すなわち患側の尿管に尿管鏡 操作を行ないやすくするために，反対（健側）の下肢 を伸展しやや外転したまま保ち術者はその外側に位置 する，図 1 に示すように左側尿管の場合には術者は患

図 1 硬珄尿管鏡操作の患者体位

A. 左側尿管結石症例に対し左側下肢挙上のみの半載 石位とする．B．術者は健側下肢の外に立ち外尿道口 より直接左尿管ロに尿管鏡を誘導する.
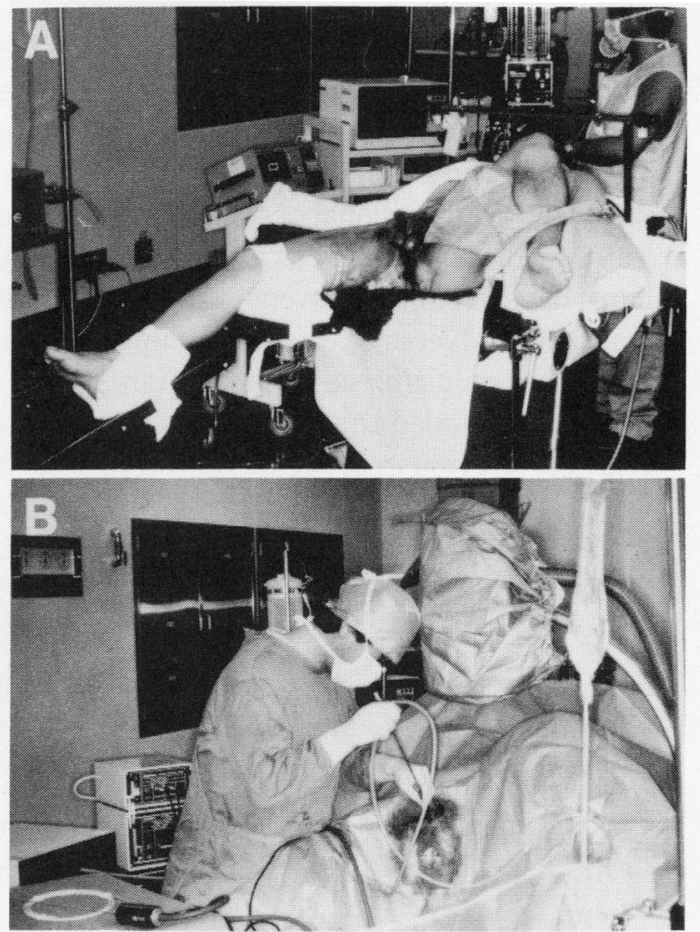
者の右下肢の右側に立ち，反対に右側尿管の場合には 術者が患者の左側に立って行ら．この手術位置は比較 的長い尿管鏡を外尿道口から壁内尿管に向かって挿入 していくのに適している。 ウレテロマットは尿管鏡に 潅流液を送るためのロータリーポンプと回路内の圧力 を測定するセンサーが備わっている7)。この圧セン サーは潅流ポンプと尿管鏡の間に設置され，あらかじ め指定した内圧レベルを越えるとポンプの回転を止め るフィードバック機構により常に希望する潅流圧で安 全に TUURSを行ならことを可能とする。潅流液には $36^{\circ} \mathrm{C}$ に暖めた生理食塩水を用い，術中に潅流液が膀胼 に貯留しないように12あるいは14F の膀胼留置バルー ンカテーテルを術直前に挿入した。通常は流量を 200 $\mathrm{ml} / \mathrm{min}$ に固定し，尿管鏡を150 200 $\mathrm{mmHg}$ で潅流し ながら外尿道口ょり尿管口まで直視下に誘導し，尿管 鏡の鉗子ロより Bentson タイプのガイドワイヤーを 尿管に捜入する。この状態で尿管口に尿管鏡の先端を 近づけることにより尿管口は潅流液の水圧により開大 し壁内尿管の粘膜を観察しうるようになる。この時点 で同じ鉗子ロからガイドワイヤーに被せるように $5 \mathrm{~F}$ のアンギオカテーテルを尿管内に插入する，TULを 目的とする場合や高度の水腎症のある症例では潅流液 が上部尿路に貯留しないよらに，尿管鏡を插入する直 前にガイドワイヤーを拔去してアンギオカテーテルの 内腔を確保し尿管内の局所的な持続潅流を行ならょう に努めた，尿管鏡の先端を壁内尿管に插入するには $120^{\circ}$ 程度に尿管鏡を回転させて尿管口粘膜を内視鏡視 野から外してアンギオカテーテルを視野の中央に捕兄 るよらに誘導した。壁内尿管に插入された時点で潅流 圧を約 $50 \mathrm{mmHg}$ 減らして安全に内視鏡視野が確保さ れる最低限の灌流圧に認定した。超音波砕石プローベ などにより鉗子ロが持続的潅流に使用できない場合に は，操作を15分毎に中断してカテーテルを腎孟内に挿 入し腎孟の減圧を行なった。尿管口の形状は Lyonの 分類 ${ }^{8}$ に従い記載した。尿管鏡の機種は $14 \mathrm{~F}$ 抽よび $12.5 \mathrm{~F}$ の尿管腎盂鏡 (ureterorenoscope, Storz)を各々 43例，および 5 例に使用した。のこりの 10 例には 13.5 F の硬性尿管鏡 (short ureteroscope，オリンパス)を 用いた，尿管内腔が粘膜浮腫あるいは繊維性の狭窄に より内視鏡の上昇が困難である場合には，潅流圧を一 時的に $200 \mathrm{mmHg}$ に高めてレントゲン透視下に $5 \mathrm{~F}$ あ るいは6F の Dotter バルーンダイレーションカテーテ ルを病変部内腔に插入し 2 気圧下で 2 分間拡張してか ら内視鏡の插入を試みた ${ }^{9)}$. 手術終了後 2 例を除く全
表 1 ウレテロマットによる尿管ロ・壁内尿管の払張 成績

\begin{tabular}{lccc}
\hline $\begin{array}{c}\text { 展 管口 } \\
(\text { Lyonの分類) }\end{array}$ & $\begin{array}{c}\text { ウレテロマット単独 } \\
\text { 成功例 }\end{array}$ & $\begin{array}{c}\text { バルーン搪張㑝用 } \\
\text { 成功例 }\end{array}$ & 㨉入不能 \\
\hline Cone 型 $(n=19)$ & 17 & 2 & 0 \\
Stadium 型 $(n=2)$ & 2 & 0 & 0 \\
Horseshoe 型 $(n=37)$ & 35 & 2 & 0 \\
\hline 合 計 $n=58$ & $54(93.1 \%)$ & $4(6.9 \%)$ & 0 \\
\hline
\end{tabular}

表 2 尿管内腔異常所見と術中処理

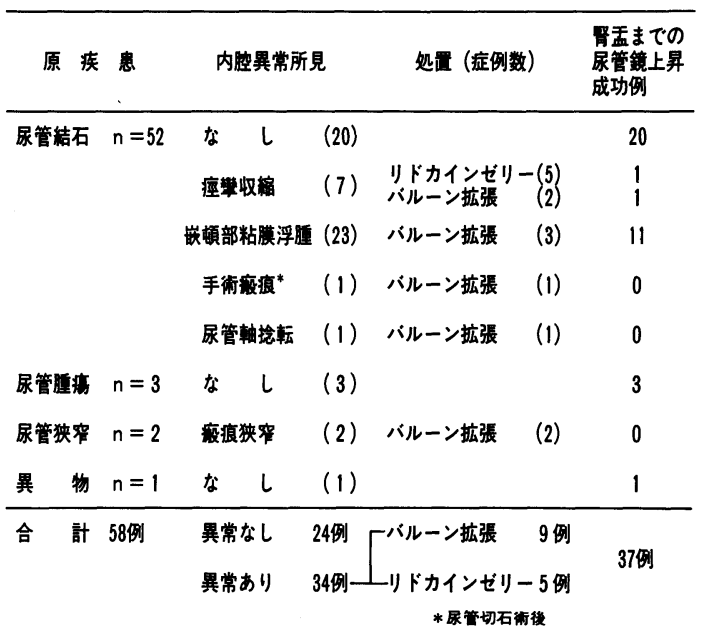

例に通常 $6 \mathrm{~F}$ の尿管ステントカテーテルを留置し48時 間後に拔去した。術後 1 力月, 3 カ月拉よび 1 年後に IVPを施行してTUURSによる合併症の有無につき 検討した。

結 果

58例に行なった TUURS の成功率を, 尿管口插入成 績と尿管内腔の通過成績にわけて表 $1 ， 2$ 亿示した。 尿管口の形態は Lyon らの分類 ${ }^{8}$ とよれば, golfhole 型 は 1 例もなく, cone 型19例, stadium 型 2 例, および horseshoe 型が37例みられた。 ウレテロマット単独で の尿管口・壁内尿管の拡張成功率は93.1\% (54/58) で,

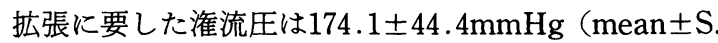
D.)であった. Cone 型ではウレテロマット単独による 払張成績がもっとも悪く $89.5 \%$ （17/19）にとどまり， stadium 型では $100 \%(2 / 2)$, horse-shoe 型では $94.5 \%$ （35/37）に成功した（表 1 ). Cone 型の 2 例および horseshoe 型の 2 例でウレテロマットによる水圧潅流 のみでは尿管口の拡張が不能であった。この 4 例では 
$6 \mathrm{~F}$ の拡張用バルーンカテーテルにより尿管口・壁内尿 管の拡張術を併用し硬性尿管鏡の插入に成功した。 こ

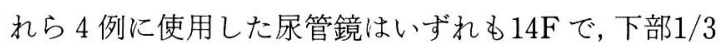
尿管結石が 2 例, 中部抒よび上部 $1 / 3$ 尿管結石が各々 1 例づつみられた。いずれの症例でも拡張終了後にウレ テロマットで潅流し壁内尿管粘膜を直視下に観察しな がら尿管鏡先端を安全に插入しえた。壁内尿管に近い 下部尿管結石は容易に確認された。最終的に尿管口の 插入には $100 \%$ に成功した.

尿管鏡の先端が壁内尿管を通過しえた時点で潅流圧 を $50 \mathrm{mmHg}$ ほど減じて安全な内視鏡視野を確保する に十分な潅流圧に調整した。尿管結石症例の $44 \%$ には 結石嵌頓部位の直下で粘膜の浮腫状変化もしくは乳頭 状の織維性上皮性增殖性変化のため通常の膀胱鏡潅流 圧 $(100 \mathrm{~cm}$ 点滴落下法) では結石は視認されにくく, 砕石や抽石操作により粘膜損傷をおこすことが予想さ れた. 尿管内腔の局所潅流用に $5 \mathrm{~F}$ のカテーテルを結石 嵌頓部位より上部に留置しながらウレテロマットで潅 流した場合には結石の全貌を観察しやすくバスケット カテーテルによる結石の捕捉や電気水圧衝撃波砕石術 (EHL)の施行が比較的に安全で容易であった（図 2).

\section{因 2 尿管鏡視野}

A. 点滴落下法によりみた内視鏡視野。尿管結石は浮 腫状粘膜により覆われている，B．ウレテロマット使 用により結石の観察が明瞭となる。

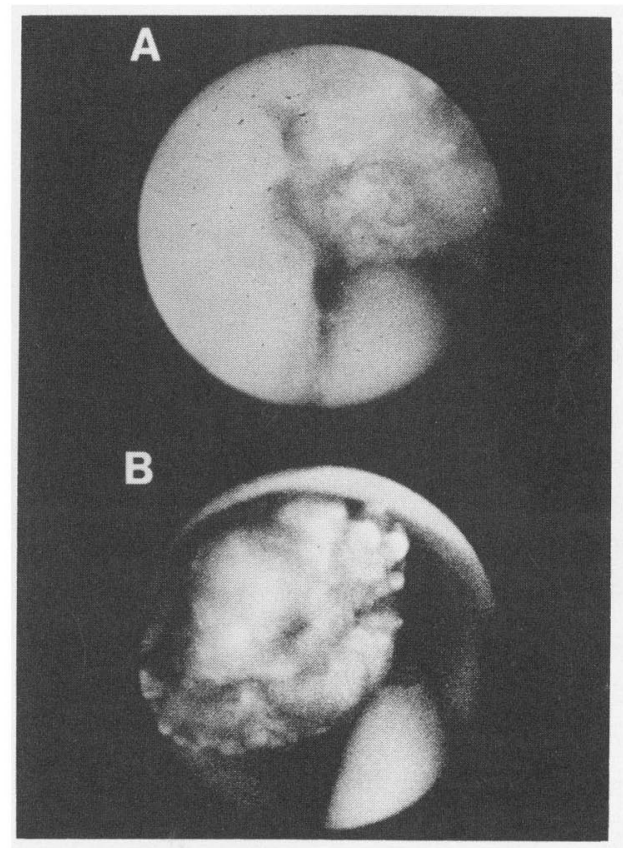

壁内尿管より中枢側の尿管内腔に尿管鏡の通過を困 難とするような内腔異常所見が 34 例に認められた. 表 2 に示すようにこの内腔異常所見は 2 例の尿管狭窄症 例を除けばすべて尿管結石症例に合併した所見であっ た. 尿管結石では嵌頓部の粘膜病変 (浮腫状変化, 乳 頭腫）が23例 (44.2\%) ともっとも多く， 㭱かに腸骨 領域での尿管の痉挛的収縮 7 例(13.5\%), 尿管切石術 後の輪状瘷痕 1 例, 骨盤腎に合併した尿管軸捻転が 1 例みられた。ここで言う尿管の㾏挛的収縮とは尿管鏡 先端より腎盂側で認められる現象ではなく,むしろす でに尿管鏡が插入されている尿管部分の機械的刺激に 対する広範な平滑筋収縮を意味する。したがって内視 鏡的には特定部位での狭窄とはとらえられず, 逆行性 尿管造影により尿管が尿管鏡と一緒に移動する所見を 得ることが特徵である。結石の腎孟内挙上を目的にし た症例で内腔の異常があり尿管鏡先端を結石部位まで 上昇させることが困難な症例では, 潅流圧を高めてガ イドワイヤーもしくは $5 \mathrm{~F}$ のンギオカテーテルで透 視下に結石を尿管嵌頓部位からはずした，尿管内腔に 異常のみられた 34 例のらち尿管鏡の通過を容易に行な らために 9 例に払張用バルーンカテーテルを用いて病 变部の拡張を試みた。この操作により嵌頓部粘膜病変 の 3 例を含む 4 例 (44.4\%) に尿管鏡を通過せしめた. 尿管の㾏挛的収縮には 5 例にリドカインゼリーを管腔 内に注入したが 1 例 (20\%) に成功したのみであった。 砕石や生検術を終えて最終的に尿管鏡を病巣部位を越 えて腎孟まで通過せしめた症例は37例であった。58例 の手術時間は65.9 32.6 分 $($ mean $\pm \mathrm{SD})$ であり, 結石 の腎孟内挙上のみを行なった 21 例の手術時間は $44.8 \pm$ 23.3分（13分９00分）であった。

表 3 に尿管結石 52 例の治療成績を示す. 52 例のうち TULの適応となった 37 例の内訳は上部 $1 / 3$ 尿管結石 3 例，中部 $1 / 3$ 尿管結石 15 例，下部 $1 / 3$ 尿管結石が 19 例 であった、結石の長径が $5 \mathrm{~mm}$ をこえる場合には超音波

表 3 尿管結石症例の治療成績

\begin{tabular}{|c|c|c|c|c|c|c|}
\hline \multirow{2}{*}{ 結 石 部 位 } & \multirow{2}{*}{$\frac{\text { 適 }}{\text { TUL }}$} & \multirow{2}{*}{$\begin{array}{l}\text { 応 } \\
\text { ESWL }\end{array}$} & \multicolumn{4}{|c|}{ 実施治療 } \\
\hline & & & TUL & ESWL & PNL & 尿管切石術 \\
\hline 上部 $1 / 3(n=13)$ & 3 & 10 & 2 & 10 & 1 & 0 \\
\hline 中部 $1 / 3(n=20)$ & 15 & 5 & 10 & 8 & 1 & 1 \\
\hline 下部 $1 / 3(n=19)$ & 19 & 0 & 18 & 1 & 0 & 0 \\
\hline 合 計 52 & 37 & 15 & 30 & 19 & 2 & 1 \\
\hline
\end{tabular}


砕石（US）もしくは電気水圧衝撃波砕石術（EHL）に より砕石してから抽石操作を行なった。22例にUSを， 8 例には EHLを施行しバスケットカテーテルによる 抽石のみを行なった症例は 8 例であった. TULはこ れら37例のうち30例（81.1\%）に成功した。 バスケッ トカテーテルにより捕捉した中部尿管結石に EHLを 併用した 1 例で尿管の avulsion を括こし，尿管切石術 を施行した。のこりの TUL 不成功例は超音波プロー べによる砕石操作中に結石が腎孟まで移動した症例で （上部尿管結石 1 例, 中部尿管結石 4 例, 下部尿管結石 1 例）あらためて経皮的腎切石術（PNL）あるいは ESWLを施行した。下部 $1 / 3$ 尿管結石に対する TUL の成功率は $94.7 \%$ であった。

尿管狭窄の 2 例は術前に膀胱鏡下に逆行性に尿管ス テントカテーテルの留置を試みたが狭窄が強く不成功 であった症例で，尿管鏡の狭窄部直下むでの捚入によ クウレテロマットで一時的な水尿管を形成し直視下に 狭窄部にカテーテルを插入することが可能となった。

58例の TUURS 症例で術中の合併症はさきに述べ た尿管の離断 1 例のほかに尿管の穿孔が 4 例みられ た.いずれの症例も TULでUS むしくはEHLによる 砕石中にレントゲン透視下に造影剂の溢流により発見 されたが，カテーテルの留置のみで軽快した。術後の 合併症としては $38^{\circ} \mathrm{C}$ 以上の発熱が 5 例 (8.6\%)，4 日 以上持続する肉眼的血尿が 5 例 (8.6\%) にみられた。 術後 IVPによりTUURSの尿管に与える影響を検討 した。尿路上皮腫瘍を疑って生検を行なった 3 例はそ の後の腎摘術（腎結核 1 例, 腎孟アミロイドーシス 1 例）もしくは尿管部分切除術（尿管ポリープ 1 例）を 行なったため TUURS の長期間にわたる影響を検討 し亲なかった。しかし手術時の所見から病巣以外に尿 管壁の絨維化を示唆する所見は認められていない， のほか術後 3 カ月以上経過観察しえなかった 5 例を除 くと50例に術後 3 力月での IVP の検討が可能であっ た。これら50例のらち2 例（4％) に腸骨領域尿管の 狭窄が認められた。いずれの症例も結石嵌頓部位に一 致し, あらためて拡張用バルーンカテーテルにより拡 張し 1 カ月間尿管ステントカテーテルを留置して経過 をみた。6 月後の IVPでは水腎症はなく狭窄は軽快 した.このほかに 3 カ月後の IVPで壁内尿管の狭窄を 疑わせる軽度の水尿管が 1 例（2％）にみられたが 1 年後でも水腎症を呈することはなく，そのまま経過を 観察中である。
考 察
尿管鏡潅流装置ウレテロマットを使用して58例に TUURS を行なった結果, 平均 $174 \mathrm{mmHg}$ の潅流圧に より $93.1 \%$ に尿管口の機械的な拡張を行なうことなく 直視下に硬性尿管鏡の插入が可能であった. TUURS でのウレテロマットの使用は, 潅流液を硬性尿管鏡の 先端から尿管口にふきつけることで尿管口および壁内 尿管を開大させたまま直視下に尿管鏡先端を挿入する ことを可能にする．この意味ではウレテロマットは尿 管口の機械的払張器具とは異なり, 尿管に与兄る物理 的ストレスは軽微でかつ可逆的である。我々の得た成 績は従来報告されている尿管口の機械的拡張法の成 績45) と比較しても劣るものではなく, 尿管口の払張時 に23F の膀脱鏡を尿道に挿入する必要がないことから 軽度の尿道狭窄を合併するよらな症例にも安全に TUURSを施行しらる利点がある。 また金属性ブジー やテフロン性ダイレーターによる拡張法では, 尿管口 は膀胱鏡により直視下に観察しながら行ないらるもの の, 壁内尿管に対してはレントゲン透視下に監視する のみで厳密な意味で内視鏡下の拡張法ではない。この 点でもウレテロマットの使用は優れており, 壁内尿管 に近い部位に嵌頓した結石症例にも安全である。最近, 棚橋 ${ }^{101}$ により先端の口径が9F で内視鏡式尿管ダイ レーターが使用可能な硬性尿管鏡が開発されている. 我々は現在まで使用する機会を得ていないが細径の内 視鏡にウレテロマットを併用すれば術後の尿管狭窄の 頻度もより少なくなると予想され, 今回報告した臨床 成績をより良いものとすると思われる。一方, 払張用 バルーンカテーテルは尿管粘膜の阻血時間を慎重に考 虑して時間を限定して使用すれば壁内尿管粘膜壊死を 起こすことなく, 比較的に安全な機械的拡張法であ $3^{9}$. 我々の今回の症例でも 4 例 (6.9\%) にウレテロ マットの使用のみでは尿管鏡の捚入が困難なため払張 用バルーンカテーテルを使用し, 最終的に $100 \%$ の尿管 鏡插入成功率を得ている，尿管口の形態で硬性尿管鏡 の插入成績に大きな差異は認められなかった。しかし cone 型でウレテロマット単独による成功率がやや劣 る傾向がみられた。

患者の体位は常に患側の下肢だけを挙上する半載石 位とし, 術者が伸展位に保った健側の下肢の外側に立 ち尿管鏡を患者の下肢に邪魔されることなく尿道, 壁 内尿管, 中部尿管の解剖学的走行に添うょ5に操作し た。この患者体位は助手に患者の両下肢間に位置する ことを容易にし，尿管鏡をはじめ長い碎石器具の術中 
の保持に役立つとともに硬性尿管鏡操作の教育にも有 用である，ただし尿管鏡の side port からガイドワイ ヤーなどを插入する場合には, side port が尿管鏡の右 側につくられているため助手との位置関係で不便を感 じることがある．とくに患者の左側に立ち右側尿管に TUURSを行う場合に助手は術者の左となり, side port から出るガイドワイヤーが術者の顔面を横切る ため滅菌したマスクを着用するか助手に充分注意させ る必要がある。術者の「きき腕，きき目」との関係は ほとんどなく，手技は簡単に慣れることができる。

壁内尿管の通過後，硬性尿管鏡の上昇に際して支障 をきたす尿管内腔異常所見が34例（58.6\%）に認めら れた。この内腔異常のなかで結石嵌頓部での尿管粘膜 病変がもっとも多く23例に, つついて腸骨領域での尿 管の㾏挛的収縮が 7 例にみられた。後者はウレテロ マットの使用に特異的なものではなく TUURSに一 般的に見られる現象である。 その原因は明らかに尿管 鏡の挿入自体による機械的刺激によるものであるが, その発生頻度は患者の身長や性別とは相関がない上う である、筆者の限られた経験からいっても尿管の痉挛 的収縮がおこり TUURSの目的が達せられない場合 には，尿管ステントを留置し 1 週間後にあらためて施 行すると機械的な拡張術を行わなくても尿管鏡の挿 入，上昇に成功することが多い，ウレテロマットによ る潅流圧の一時的な増加のみでは尿管の痉挛的収縮や 浮腫状の粘膜变化を著明に改善することはできなかっ た. 今回は一期的に TUURSを行った症例のみををと めて報告したが，拡張用バルーンカテーテルにより尿 管鏡の上昇が $44 \%$ (4/9) で可能となった，尿管の痓挛 的収縮に対してはリドカインゼリーの注入を行なった が20\%（1/5）に成功したのみであった。このような処 置に反応しない症例に対してTUURSまたはTUL を強行することは危険であり, 尿管結石症例であれば 結石を腎皿内に挙上するか尿管にステントカテーテル を留置して後日 TULを試みるべきである11).

TUURS にウレテロマットを使用する利点は尿管 口の拡張以外に尿管内腔をつねに明瞭な視野で観察す ることができる点にある7).とくに嵌頓部で結石が粘 膜に覆われ破砕が困難であるような症例では, ウレテ ロマットの潅流指定圧を一時的に $200 \mathrm{mmHg}$ まで上昇 させることにより結石の嵌頓部位をこえてガイドワイ ヤーの挿入が容易に行なわれた。このような症例には 原則としてバルーンカテーテルにより嵌頓部を払張し 結石を確認できるようにしてから砕石した。また尿管
の㾏挛的収縮のために尿管鏡の上昇が困難であった症 例でも, ウレテロマットの一時的な加圧により結石を 腎盘内に挙上することに失敗した症例はなかった。

ESWL には第二世代の砕石装置 (ピェゾリス 2200 , Wolf) ${ }^{12)}$ 用いたが，この砕石装置により無麻酔で砕 石が可能であり腎孟内に結石を挙上した翌日には砕石 することが可能であった. 52例の尿管結石症例のなか でTULの適応となった37例のうち完全に結石を除去 しえた症例は30例（81.1\%）であった。 ウレテロマッ トによる潅流もしくは尿管内腔拡張効果により碎石中 に結石が䐌孟内に移動してしまった症例は 6 例 (16.2\%)にみられた。この砕石中にみられた結石の腎 孟内迷入率は通常の点滴落下による尿管鏡潅流法に よって行なわれた TULの諸家の報告 $\left(1.6^{13)}\right.$ $\sim 10.2 \%)^{6)}$ より高くウレテロマット使用の欠点とも 言える。しかし中部尿管以上の尿管結石の腎㙉内への 移動は ESWL が普及した現在, もはや TUL の失敗例 と考学る必然性はない）。

ウレテロマットの使用により腎血内圧が潅流液の貯 留により高まり pyelotubular backflow が起こりらる が，この予防のためにもできるだけカテーテルを用い て局所持続潅流を行ならかあるいは15分間隔で腎孟内 の減圧を扢こなった. 我々の経験した症例では術後一 過性の発熱 ( $38^{\circ} \mathrm{C}$ 以上) は $8.6 \%$ に認められた。いずれ の症例も抗生物質の投与で術後 3 日以内に平熱となっ た。他家の報告では術後に抢こる発熱の頻度は従来 $5.7^{13)} \sim 11.6 \%^{2)}$ とされており, ウレテロマットの使用 によりみられた頻度は特に高いものではないと考兄ら れる. Lyon ら゙は TUURSには潅流圧を最小限にし て pyelorenal back flowを防ぐべきであると述べて いる。しかし尿管の㾏挛的収縮がおきた場合や内視鏡 視野が充分でない場合には, side port から注射器でキ シロカインゼリーあるいは生理食塩水を注入せざるを 得ない。この操作は短時間といえども上部尿路内の潅 流圧を予想以上に高めることはあまり知られていな い. Eshghi ${ }^{14)}$ によればこのような注入により腎血内圧 は $350 \mathrm{mmHg}$ にも上昇するとされており，また最近の Kitamura ら ${ }^{15}$ の報告でも50ml の注射器を使用して 手押しで硬性尿管鏡の side port からゆっくりと注入 しても内圧は $195 \mathrm{mmHg}$ まで上昇するとされている。 TUURS におけるこれらの注入操作は内圧の急激な 変化をおこしやすく，またとくに内圧を監視しないで 行らとウレテロマットで常時定圧下に潅流を行ら場 合よりも腎孟内圧をより高めやすく pyelorenal back- 
flowを招こす危険は無視できないものがある。一方ウ レテロマットで得られた潅流圧は平均 $180 \mathrm{mmHg}$ (239 $\mathrm{cmH}_{2} \mathrm{O}$ ) に近く常に一定圧を保ち得るものの非生理的 であることにかわりはない。事実われわれが最近報 告 ${ }^{16)}$ した動物実験でも潅流圧 $100 \mathrm{mmHg}$ で20分間隔で 腎孟内減圧注入をくりか兄し 1 時間行った場合, 潅流 液の体内吸收は認められないが組織学的に pyelotubular backflow が100\%認められている。この 点はウレテロマットを使用するに際して充分考慮され るべきで, 未治療の尿路感染症を伴う症例で使用され てはならない。また尿管の㾏挛的収縮がおこり潅流液 の膀胼への逆流が極端に限られた状態で長時間の潅流 を行うことはできるだけ避けるべきである.

機械的拡張法により施行されたTUURSに特有の 合併症としてこのほかに壁内尿管の狭窄が1.4 $4^{2)}$ $\sim 5.3 \%^{17)}$ の頻度で認められることが報告されている. 報告によっては狭窄が著しいため尿管膀胱新吻合術を 必要とする症例も散見される ${ }^{217)}$. 今回集計したウレ テロマット使用例ではわずかに $2 \%$ 軽度の狭窄を認 めたのみで中部尿管の損傷により尿管結石術を行なっ た 1 例を除き開腹手術を要するにいたった症例はな く, その操作の安全性が確認された。

\section{結 語}

58例に行なった TUURS の経験から, ウレテロマッ 卜の使用は硬性尿管鏡の操作を従来の下部尿路内視鏡 と同様に外尿道口から特別の処置をせずに短時間で安 全に施行することを可能にした。 ウレテロマットによ る潅流により尿管口の $93 \%$ は機械的拡張操作なく硬性 尿管鏡の挿入が可能となり，下部 $1 / 3$ 尿管結石に対する TULはより安全で成功率の高いものとなった。腸骨 領域以上の結石に対しては嵌頓部位の粘膜の浮腫状変 化が強く砕石操作が困難な場合には比較的容易に腎典 内への挙上を行ないESWLによる治療を選択するこ とも可能であり，ウレテロマットはこのような操作に もきわめて有用であると考えられた。

\section{文献}

1) Perez-Castro, E. and Martinez-Pineiro, J.A.: Transurethral ureteroscopy-A current urological procedure. Arch. Exp. Urol., 33, 445, 1980.

2) Lingeman, J.E., Sonda, P., Kahnoski, R.J., Coury, T.A., Newman, D.M., Mosbaugh, P.G., Mertz, J.H.O., Steele, R. and Frank, B.: Ureteral stone management: Emerging concepts. J. Urol., 135, 1172-1174, 1986.

3) Lyon, E.S., Huffman, J.L. and Bagley, D.H. :
Ureteroscopy and ureteropyeloscopy. Urol. Special Issue., 23, 29-36, 1984.

4) Huffman, J.L., Bagley, D.H. and Lyon, E.S.: Treatment of distal ureteral calculi using rigid ureteroscope. Urol., 20, 574-577, 1982.

5) Politis, G. and Griffith, D.P.: Ureteroscopy in management of ureteral calculi. Urol., 30, 39-42, 1987.

6) Lytton, B., Weiss, R.M. and Green, D.F.: Complicatin of ureteral endoscopy. J. Urol., 137, 649-653, 1987.

7) Perez-Castro, E., Mancebo, J.M. and Massarra, J.: Method to obviate dilation in ureterorenoscopy. Uromat. J. Endourol., 1, 223-226, 1987.

8) Lyon, R.P., Marshall, S.K. and Tanagho, E.A.: The ureteral orifice: Its configuratin and competency. J. Urol., 102, 504-509, 1969.

9) Baba, S., Marumo, K., Honda, T.A., Ido, K., Ohkuma, K., Tachibana, M., Jitsukawa, S., Deguchi, N., Hata, M. and Tazaki, H.: Balloon dilatin of edematous ureteral segment in percutaneous ureterolithotripsy for long-term impacted calculi. J. Endourol., 1, 227-234, 1987.

10）棚橋善克：経尿道的腎尿管結石摘出術. 臨泌，42, 207-213, 1988.

11）川村直樹, 西村泰司, 秋本成太：硬性尿管鏡による 経尿道的尿管結石摘出術. 泌尿器要, 32, 533-539, 1986.

12）馬場志郎, 出口修宏, 早川邦弘, 㰌 政昭, 実川正 道, 畠 亮, 田崎 寛: 圧電式腎結石破碎装置に よる無麻醉体外衝撃波腎碎石術の経験. 日泌尿会 誌, 79, 1917-1925, 1988.

13）小野佳成, 平林 聡, 山田 伸, 大島伸一, 絹川常 郎, 松浦 治, 加藤範夫, 杉山寿一, 渡辺丈治: 経 尿道的尿管結石除去術の検討. 日泌尿会誌, 78, 1917-1922, 1987.

14) Eshghi, M.: Pressure-controlled hydraulic dilation of the ureter: One-step ureterorenoscopy. J. Urol., 140, 950-956, 1988.

15) Kitamura, T., Doi, N., Takahashi, S., Moriyama, N., Fukutani, K., Kawabe, K. and Aso, Y.: Maximum pressure in the ureter during TUL. Jap. J. Endourol., 1, 61, 1988.

16) Baba, S., Nakanoma, T., Hayakawa, K., Nagahama, T. and Marumo, K.: Does high pressure irrigatin of renal pelvis by ureteroscopy cause irrigant absorption? Jap. J. Endourol., 1, 60, 1988.

17) Dretler, S.P.: Laser photofragmenttatin of ureteral calculi : Analysis of 75 cases. J. Endourol., 1, 9-14, 1987.

（1989年 3 月 28 日受理） 